\title{
Relationship between body condition score, body weight, some nutritional metabolites changes in blood and reproduction in Algerian Montbeliad cows
}

\author{
C. Mouffok*, T. Madani ${ }^{1}$, L. Smara, M. Baitiche, L. Allouche, F. Belkasmi \\ Department of Agronomy, Faculty of SNV, Setif University Algeria. \\ 1. Formation and Research Directory. Department of Agriculture, Algeria. \\ * Corresponding author email : mouffokcharefeddine@yahoo.fr \\ Received: 05-04-2011, Accepted: 08-05-2011, Published Online: 05-09-2011 \\ doi: $10.5455 /$ vetworld.2011.461-466
}

\begin{abstract}
The objective of this study was to investigate through a nutritional and biochemical approach the variability of reproductive performance in dairy cows of semi arid area herds. Seventy four multiparous females reared in four farms were tracked from one month before calving to the third month postpartum. Information about reproductive events were taken once a month, and the body condition score evaluated on a 1 to 5 scale according to the EDMONSON method (1989). Blood samples were taken on a sample of 23 cows chosen according to body condition score before calving for biochemical analysis of energy, nitrogen and minerals parameters. Maximum concentrations depended to physiological stage. Blood glucose and calcium are stable at around $0.60 \mathrm{~g} / 1$ and 0.76 $\mathrm{g} / 1$ respectively $(\mathrm{p}>0.05)$. Uremia $(0.27 \mathrm{~g} / \mathrm{l}$ vs $0.16 \mathrm{~g} / \mathrm{l})$ and triglycerides $(0.74 \mathrm{~g} / \mathrm{l} \mathrm{vs} 0.48 \mathrm{~g} / \mathrm{l})$ are higher in the first month of lactation ( $\mathrm{p}<0.05)$. Cholesterol $(1.42 \mathrm{~g} / \mathrm{l} \mathrm{vs} 1.03 \mathrm{~g} / \mathrm{l})$ is higher in the 3rd month post-partum. The results show also that best performances are recorded in cows with $\mathrm{BC}$ before calving around 3 and $3.5(\mathrm{p}<0.05)$ and for those loosing less BC in the first months postpartum. The nutritional and metabolic profiles of females were used to characterize high female performance which has a reduces format and losses of BC in post-partum are minimal and late; They express the moderate concentration of glucose $(0.60 \mathrm{~g} / 1)$, elevated cholesterol $(>1.20 \mathrm{~g} / \mathrm{l})$ and low triglycerides (about $0.60 \mathrm{~g} / 1$ ). Great format Cows with early and significant loss of BC after calving. They express a poor reproductive performance with high triglycerides concentration $(1.02 \mathrm{~g} / \mathrm{l})$ in the $1 \mathrm{st}$ month of lactation.
\end{abstract}

Keywords: Reproduction, Dairy cows, Body condition, Biochemical parameters, Semi arid.

\section{Introduction}

The body condition (BC) of dairy cows in pre and post-partum modulate reproductive performance (Castaneda-Guti'errez et al. 2009) and milk production (Jilek et al. 2008). The effects of nutrition on reproductive efficiency of females were clearly demonstrated by several studies. Short et al. (1990) reported that lactating cows reduced feed intake before calving is reflected by lowest body condition at calving accompanied to long postpartum anoestrus. Also, it was demonstrated that undernutrition and low body condition score during the first phase of lactation is accompanied by disorders in plasma concentrations of reproductive hormones (Westwood et al. 2002), low follicle development (Fassi Fihri et al. 2005) and poor oocytes quality (Jorritsma et al.2003).

A distinction has been made by researchers between body condition score and energy balance during the first period of lactation. For Baumgard et al. (2006), most dairy cows come in negative energy balance after parturition, which is a normal adaptation to lactation. This situation is independent of the genetic potential of milk yield. Bukley et al. (2003) reported that it is the severe energy balance which causes metabolic disorders and impaired fertility. Contrariwise, Grimard et al. (2003) observed an improvement in fertility by equilibration of energy balance even if the body condition score remains low.

The estimation of body condition scoring by notation though is simple and subjective it allows an indirect measure of the energy status of females. However, it can be enhanced by objective measure-ments such as biochemical analysis of blood parameters to understand and explain biologically loss or recovery in $\mathrm{BC}$ and its impact on reproduction (synthesis and secretion of sex hormones, toxicity, etc.)

This study aims to clarify through a nutritional 
Relationship between some parameters in Algerian Montbeliad cows

Table-1 : Means and ratios of BCS before calving class in cow population and sample

\begin{tabular}{|c|c|c|c|c|c|c|c|}
\hline \multirow[t]{2}{*}{ Particulars } & \multirow[t]{2}{*}{$\mathbf{n}$} & \multicolumn{5}{|c|}{ BCS before calving } & \\
\hline & & \multicolumn{2}{|c|}{$<2.75$} & \multicolumn{2}{|c|}{$2.75-3.50$} & \multicolumn{2}{|c|}{$>\mathbf{3 . 5 0}$} \\
\hline Population & $\begin{array}{l}74 \\
23\end{array}$ & $\begin{array}{l}\text { Means } \pm \text { SE } \\
2.38 \pm 0.07 \\
2.25 \pm 0.14\end{array}$ & $\begin{array}{l}\% \\
16 \\
13\end{array}$ & $\begin{array}{l}\text { Means } \pm \text { SE } \\
3.16 \pm 0.04 \\
3.00 \pm 0.04\end{array}$ & $\begin{array}{l}\% \\
46 \\
39\end{array}$ & $\begin{array}{l}\text { Means } \pm \text { SE } \\
4.16 \pm 0.07 \\
4.23 \pm 0.11\end{array}$ & $\begin{array}{l}\% \\
38 \\
48\end{array}$ \\
\hline
\end{tabular}

and metabolic approach the effects of body condition before calving and its evolution dynamics in post partum on the changes of blood biochemical parameters related to food energy, nitrogen and mineral and reproductive behaviour of cows. In addition, the accuracy of best $\mathrm{BC}$ and evolution type adapted to a good reproductive rate and dietary recommendations needed to establish the ideal BC when desired.

\section{Materials and methods}

Animal material: The study was done in four larges farms in eastern semi arid area of Algeria. Seventy four Montbeliard cows of different ages are followedup around one month before calving to the $4^{\text {th }}$ months of lactation. Twenty three of them are chosen for blood sampling.

Body condition score and body weight measurement: The body condition score (BCS) was estimated monthly on a 1-5 scale (Edmonson et al. 1989). A tape measure for cattle is used to estimate the body weight (BW) by measuring the girth.

Nutritional parameters in blood: A sample (23 cows) of the initial population was chosen to perform blood tests to make determinations of energy, nitrogen and mineral metabolites. The choice was made so as to cover all classes of body condition before calving (Table-1).

The samples were taken in the last month of gestation, 30, 60 and 90 days of lactation. For each animal a sample of $10 \mathrm{ml}$ of blood was taken from coccygeal vessels on a Vacutainer ${ }^{\circledR}$ tube without anticoagulant. Then $5 \mathrm{ml}$ of the sample is poured immediately into a lithium heparin tube. All blood samples were carried early in the morning before the distribution of concentrate. At laboratory, blood was centrifuged at 3000rpm for 5 minutes. The plasma and serum are passed directly back to a multi autoanalyzer for determination of glucose, cholesterol, triglycerides, urea, creatinine and calcium concentration using enzymatic reactions with commercial kits (Spainreact (B) for metabolites considered.

Reproduction parameters: Five reproductive traits were analyzed:

- Calving to first service interval (FSI);
- Calving to conception interval(CI);

- First service to conception interval;

- Number of services per conception;

- Conception rate at 60, 90 and 120 day after calving (CR)

Statistical analysis: All data are then subjected to several statistical analyses to study the relation between body condition and the variability of blood metabolites and its impact on reproduction.

The data were presented as least square means (LS mean \pm S.E.). A two step classification was used to separate classes with different BC before calving. Class distribution is only accepted if the cohesion and separation index is greater than 0.5. PCA follows a hierarchical classification of reproductive parameters is performed to identify the different types of performances. The analysis of variance single factor (SPSS Procedure 18) was used to analyse the effect of age and season on reproductive parameters. The evolution of the BC, BW and nutritional metabolites was subjected to analysis of variance with repeated measures (LGM procedure) indicating the variability between physiological stage.

Given the small size of the sample, the KruskalWallis nonparametric analysis was conducted to describe the variability of reproductive parameters and blood metabolites by BC classes. The significance level was set at 0.05 . When the effect of class was significant, regression test were established to determine the type of evolution. All analysis were performed by SPSS (18).

\section{Results}

Dynamic changes of BCS and BW: Similar evolution shape of $\mathrm{BC}$ and $\mathrm{BW}$ in pre and post partum was observed. The best records are stored in dry periods (3.46 and $638 \mathrm{~kg}$ of BC and BW respectively). Both parameters undergo a decrease equivalent to 5 to $6 \%$ in post-partum to reach a minimum in the 2 nd month of lactation $(\mathrm{p}<0.001)$. The recovery status is established from the 3rd month when $\mathrm{BC}$ and $\mathrm{BW}$ represent $96 \%$ and $98 \%$ of initial situation.

Dynamic changes of metabolite profile Energetic metabolites: Changes in blood 
Relationship between some parameters in Algerian Montbeliad cows

Table-2: Reproduction traits in Montbeliard cow

\begin{tabular}{llll}
\hline Reproductive parameters & $\mathbf{n}$ & Mean & SE \\
\hline FSI (day) & 74 & 58 & 4.03 \\
CI (day) & 74 & 86 & 6.56 \\
FSCI (day) & 74 & 28 & 5.43 \\
SPC & 74 & 1.85 & 0.15 \\
CP $(60 \%)$ & 33 & 45 & --- \\
CP $(90 \%)$ & 45 & 61 & -- \\
CP $(120 \%)$ & 58 & 79 & - \\
\hline
\end{tabular}

concentrations of energy metabolites revealed three profiles. Glucose variability is low and stagnant at a concentration of $0.6 \mathrm{~g} / \mathrm{l}$. However, the blood concentration of cholesterol shows low around calving $1 \mathrm{~g} / \mathrm{l}$, but increases rapidly and significantly $(p<0.05)$ from the 2 nd month to be higher than $1.4 \mathrm{~g} / 1$. Triglycerides are moving in the opposite direction. This rate is relatively moderate in dry $(0.62 \mathrm{~g} / \mathrm{l})$ increases rapidly and significantly $(\mathrm{p}<0.05)$ after calving and then decreases in the 2 nd month to stabilize around $0.50 \mathrm{~g} / \mathrm{l}$.

Nitrogen metabolites: Uraemia average in dry is approximately $0.17 \mathrm{~g} / 1$, then increases $(\mathrm{p}<0.05)$ in the $1^{\text {st }}$ months of lactation $(0.27 \mathrm{~g} / \mathrm{l})$ and begins to decline from $2^{\text {nd }}$ month $2(0.24 \mathrm{~g} / 1)$ to return to the dry value in $3^{\text {rd }}$ month of lactation $(0.19 \mathrm{~g} / 1)$.

However, the variability of creatinine is low with a high relative value before calving $(0.20 \mathrm{~g} / \mathrm{l})$ and a low in post partum $(0.16 \mathrm{~g} / \mathrm{l})$.

Mineral metabolites: The calcium concentration does not vary significantly ( $p>0.05)$ around calving and the differences between stages are less than $0.08 \mathrm{~g} / 1$.

Reproductive parameters: The reproductive performances of cows are summarized in the table- 2 . The averages FSI, CI, FSCI and NSC are 58, 86, 28 and 1.85 respectively. Indeed, $45 \%$ of cows are seen pregnant at 60 days and $79 \%$ to 120 jours. These performances are related to calving season $(\mathrm{p}<0.001)$ but are independent at the age of females ( $>>0.05)$. The best performances were recorded in summer.

\section{$B C$, metabolites and reproduction}

I mpact of BCS before calving: According to the classes previously identified by two step classification it was found that BCS before calving affects reproductive parameters mainly FSI and CI ( $<<0.05)$. Regression analysis shows a strong relationship between these parameters. The $\mathrm{BC}$ before caving is strongly correlated with FSI $(p=0.012, r=0.61)$ and relatively correlated with $\mathrm{CI}(\mathrm{p}=0.097, \mathrm{r}=0.47)$. The best performances were recorded in females with medium BCS (2.75 to 3.50$)$ whose reproductive intervals were shorter (54 and 81days of FSI and CI respectively), obese cows show average performance (71 and 85days). However, lowest performances were observed in thins cows (131 and 150 days).

For the biochemical parameters of energy metabolism, the Kruskal Wallis test shows that the BC before calving has little effect that manifests only in one stage. Regression confirms the significant effect of the $\mathrm{BC}$ before calving on blood glucose of dry cows for obese cows $(0.67 \mathrm{~g} / 1 \mathrm{vs} .0 .52 \mathrm{~g} / 1)$. Cholesterol in the first months of lactation is higher in cows with medium BCS (1.18 g / 1) compared to obese cows $(0.89 \mathrm{~g} / \mathrm{l})$. However, the level of triglyceride in serum is greater in thins cows $(0.91 \mathrm{~g} / \mathrm{L}$ vs $0.51 \mathrm{~g} / \mathrm{l})$.

Uraemia in dry evolves linearly according to the BCS before calving, it is lower in thins cows $(0.09 \mathrm{~g} / \mathrm{l})$ and higher among those obese $(0.23 \mathrm{~g} / 1)$.

Nutritional and Metabolic Characteristics of high, medium and low cow performance

The principal component analysis (PCA) followed by hierarchical cluster analysis of reproductive parameters data allowed us to identify three classes of cows whose performances are distinguished (table-3). However, there are also differences in dynamics change of body condition and blood concentrations of triglycerides, cholesterol and urea. The first class includes adult cows (older than 5 years). Their reproductive performance is better; FSI and CI are equivalent to 43 and 56 respectively. Body condition is characterized by a good rating in dry, a low and early

Table-3: Reproduction traits in classes identified by PCA

\begin{tabular}{llllllll}
\hline & Significant & \multicolumn{2}{l}{ Class 1 (50\%) } & \multicolumn{2}{c}{ Class 2 (40\%) } & \multicolumn{3}{c}{ Class 3 (10\%) } \\
& & Mean & SE & Mean & SE & Mean & SE \\
\hline $\mathrm{FSI}$ & $\mathrm{p}<0.001$ & $43^{\mathrm{a}}$ & 5.01 & $115^{\mathrm{b}}$ & 6.16 & $44^{\mathrm{a}}$ & 0.00 \\
$\mathrm{CCl}$ & $\mathrm{p}<0.001$ & $56^{\mathrm{a}}$ & 6.04 & $123^{\mathrm{b}}$ & 7.87 & $157^{\mathrm{b}}$ & 0.50 \\
$\mathrm{FSCl}$ & $\mathrm{p}<0.001$ & $13^{\mathrm{a}}$ & 6.58 & $8^{\mathrm{a}}$ & 4.26 & $114^{\mathrm{b}}$ & 0.50 \\
$\mathrm{NSC}$ & $\mathrm{p}>0.05$ & 1.55 & 0.28 & 1.33 & 0.16 & 2.00 & 0.00 \\
\hline \hline
\end{tabular}


loss and significant recovery. The concentration of glucose is constant around $0.60 \mathrm{~g} / 1$ but cholesterol appears very high compared to other groups with a max at $3^{\text {rd }}$ months. In contrast, the plasma triglyceride concentration is low. Changes in blood urea concentration are low and stagnant in $0.20 \mathrm{~g} / 1$ level.

Class 2 contains cows with bad performances. The FSI and CI are 115 days and 123 days respectively. They were thin cows who suffer loss continues until the $2^{\text {nd }}$ month of lactation, the recovery is tardy. Blood glucose of cows is stable at around $0.58 \mathrm{~g} / \mathrm{l}$.

Cholesterol is low in dry and early lactation and increases thereafter. Triglycerides are higher compared to the first. Uraemia is low before calving increases and stabilizes around $0.25 \mathrm{~g} / \mathrm{l}$ after $1 \mathrm{st}$ month of lactation.

Class 3 includes repeat breeding cows. Making in breeding is early (44 days) but conception will occur after 5 months. The FSCI is very long (113 days). Females of this class have a good body condition at calving who suffers a significant loss in the first months of lactation (24\%). Cows in this group express blood glucose concentrations relatively higher compared to other groups. Cholesterol is low before calving increase continually until the $2^{\text {nd }}$ month and decrease after. Triglycerides are low in dry and early lactation, increased significantly in the 2 nd month post partum and decrease later. Uraemia follows the same profile of blood cholesterol with a peak in the $2^{\text {nd }}$ month and minimum values for dry and $3^{\text {rd }}$ months of lactation.

\section{Discussion}

The study of reproduction in Montbeliard race reared in Algerian semi arid region shows relatively good performance. Calving to first service interval and calving to conception interval evaluated at 58 and 86 days was similar to the performances in temperate countries (Gillund et al. 2001; Pryce et al. 2001; Veerkamp et al. 2001) and are best compared to the results in similar conditions (Madani and Mouffok 2008; Sraïri and Baqasse, 2000; Van Sanh et al. 1997). The intra-annual variability is much documented, but the differences are different in direction and value. Pryce et al. (2000) showed that in the United States and in Ireland, females calving in the period from January to May realize the longer intervals. However, Gillund et al. (2001), observed in the Scandinavian country a better performances for summer calving resulted in a gain of 10 to 14 days compared to winter. In contrast, $\mathrm{N}$ dama cow in Africa realize low performance in summer (Kang'mate et al. 2000).
Contrwise, other authors reported that the calving season had no effect on reproductive performance (Mouffok et al 2007; Resken et al. 1999).

In our case improvement is observed from winter to summer. This variability can be explained by animal level of body reserves recovered during spring (period of high forage potential) and its effects on post partum energy balance (EB). The relationship of EB with reproductive performance has been well documented. For BANOS et al. 2004, the negative energy balance is associated with difficulties encountered by the cow to receive and maintain the fetus. These problems are more noticeable in highly productive cows' milk. Royal et al. (2002) reported that in dairy cows, negative EB is the result of strong activity of hormones that regulate metabolism through the mobilization of body reserves. This activation promotes the alteration of reproductive hormones flow. An adequate energy supplements before and after calving can correct this negative balance (Staples et al. 1998; Pruit, 2001). Cavestony et al (2009) reported the correction of $\mathrm{EB}$ is valid only in multiparous. Primiparous continues to lose, at all level of complementation. In this study reproductive parameters are correlated to $\mathrm{BC}$ before calving. The best performances are expressed by cows with BCS between 3 to 3.5 points. Shrestha et al. (2005) and Jilek et al. (2008) observed that no significant effect of the BCS at dry period resumption of luteal activity and breeding in the Holstein and Fleckvieh breed. However, the authors report that cows that loses more express longest postpartum intervals (EscobedoAmezcua et al. 2010). In addition the BC is positively correlated with glucose and urea, a sign of good food practice. Blood concentrations of glucose and urea are higher in obese dry cows thus confirming works of Tillard et al (2007) in Holstein in Indian pacific conditions. From that, urea concentration increased significantly in the first months in thins and declines then. However, urea evolution is regular in obese cows. The energy deficit decrease insulin and IGF-I secretion and inhibits hypothalamic GnRH, pituitary LH and FSH secretion (Castaneda et al. 2009) and reducing maturity and production of estrogen by ovarian follicles (Butler 2000).

However, triglycerides are moving in the opposite direction. Thin cows have the highest concentrations at dry following an intense lipolysis (3c). In postpartum, triglycerides values increase to the $1^{\text {st }}$ month result mobilization of body reserve to support milk production but will go down from the $2^{\text {nd }}$ 
month to be at low levels indicating that recovery of body condition are established. According to Chillard (1998) triglycerides are produced by the liver from free fatty acids released from adipose tissue at the time of mobilization of corporal reserves. In contrast, average concentrations were observed in cows with higher BCS (> 3.5).

In our study, cholesterol is negatively correlated with protein intake. Its content is higher in cows with medium BC at any stage result a better reproductive performance. Obese and thin cows reveal similar low levels before calving and diverge from the $1^{\text {st }}$ month of lactation when we observe a decrease of cholesterol concentration in obese cows and an increase in thin cows. At the 3 rd month rates return to base value.

Three groups of cows of various reproductive performances are identified by PCA. Poor reproductive cows with a body condition, plasma glucose and cholesterol relatively low. But high triglycerides and moderate urea concentration were observed. Although glucose is no considered as a very sensitive indicator of energy status due to homeostasis (Kronfeld et al 1982) cholesterol is considered the most reliable among the blood parameters. Ruegg et al. (1992) found that cholesterol is inversely correlated to loss of $\mathrm{BC}$ in post-partum; more than energy deficit is higher cholesterol is low. However, Roche (2006) reported that cows with a low body condition at calving tend to prolong postpartum anoestrus probably due to the low frequency pulses of $\mathrm{LH}$, reflecting a decrease in estradiol concentration becomes ineffective to induce LH discharge and ovulation.

Both cows with best performances reproduction and repeat breeding start with a high BCS at dry. A high significant loss of $\mathrm{BC}$ at $1^{\text {st }}$ month is observed in repeat breeding cows. Plasma concentrations of glucose and cholesterol levels are high and cows come into heat early (43 et 44 day). However, these females recorded relatively low concentrations of triglycerides and urea before calving and rapidly and significantly increasing in repeat breeding cows' post-partum. The increase in postpartum blood triglycerides is an indicator of a strong mobilization of body reserves that interfere with the success of conception. The increase in blood urea can decrease fertility rate (Ling et al. 2003) by increasing the plasma concentration of progesterone (Barton et al. 1996). However, Elrod and Butler (1993) reported that high levels of uraemia may reduce fertility by destroying sperm or embryo mortality in early stages of development.

\section{Conclusion}

The results show that best performances are recorded by cows having $\mathrm{BC}$ before calving overweight between 3 and 3.5 and for those who lose less in the first months postpartum. The nutritional and metabolic profiles of females was used to characterize high female performance which has a reduces format and losses of $\mathrm{BC}$ in post-partum are minimal and late; They express the moderate concentration of glucose $(0.60 \mathrm{~g} / \mathrm{l})$, elevated cholesterol (> $1.20 \mathrm{~g} / \mathrm{l})$ and low triglycerides (about $0.60 \mathrm{~g} / \mathrm{l}$ ). Great format Cows with early and significant loss of BC after calving. They express a poor reproductive performance with high triglycerides concentration $(1.02 \mathrm{~g} / \mathrm{l})$ in the $1 \mathrm{st}$ month of lactation.

\section{Acknowledgements}

The authors thanks the head of farms Khababa, Laghmara, Mekhloufi and Chekhchoukh who have given the permission to use the animals for study. Our sincere thanks are also directed to Prof. Khaled Abbas Director of Research at the National Institute of Agronomic Research for his contribution to correction and improvement of document.

\section{References}

1. Banos, G., Brotherstone, S., Coffey, M.P (2004). Evaluation of body condition score measured throughout lactation as an indicator of fertility in dairy cattle. J. Dairy Sci. 87: 2669-2676.

2. Barton, B.A., Rosario, H A., Anderson, G.W., Grindle, B.P., Carroll D.J (1996). Effects of dietary crude protein, breed, parity, and health status on the fertility of dairy cows. J Dairy Sci 79: 2225-2236

3. Baumgard, L.H., Odens, L.J., Kay, J.K., Rhoads, R.P. Vanbaale, M.J., Collier, R.J (2006). Does negative energy balance (NEBAL) limit milk synthesis in early lactation? $21^{4}$ Annual Southwest Nutrition \& Management Conference. February 23-24, 2006., Tempe, 181- 187.

4. Buckley, F., Mee, J., O'sullivan, K., Evans, R., Berry, D. Dillon, p (2003). Insemination factors affecting the conception rate in seasonal calving Holstein-Friesian cows. Reprod. Nutr. Dev. 43: 543-555.

5. Butler, W.R (2000). Nutritional interactions with reproductive performance in dairy cattle. Anim Reprod Sci $; 60: 449-57$.

6. Castaneda-Guti'errez, E., Pelton, S.H., Gilbert, R.O. Butler, W.R (2009). Effect of peripartum dietary energy supplementation of dairy cows on metabolites, liver function and reproductive variables. Anim Reprod Sci; 112.301-315

7. Cavestany, D., Vinoles, C., Crowe, M.A., La Manna, A., Mendoza, A (2009). Effect of prepartum diet on postpartum ovarian activity in Holstein cows in a pasture-based dairy system. Anim Reprod Sci; 114 1-13

8. Chillard, Y., Bocquier, F., Doreau, M (1998). Digestive and metabolic adaptations of ruminants to undernutrition, and consequences on reproduction. Repro. Nutr. Dev, 38 : 131152.

9. Edmonson, A.J., Lean, I.J., Weaver, L.D., Farver, T.,Webster, G (1989). A body condition scoring chart for holstein dairy cows. J Dairy Sci, 72: 68-78. 
10. Elrod, C.C., Butler, W.R (1993). Reduction of fertolity and alteration of uterine $\mathrm{pH}$ in heivers fed excess ruminally degradable protein. JAnim Sci, 71:694-701.

11. Escobedo-Amezcua, F., Nuncio-Ochoa M, G.J., HerreraCamacho, J., Gomez-Ramos, B., Segura-Correa, J.C., Gallegos-Sanchez, J (2010). effect of restricted suckling on body weight, body condition score and onset of postpartum ovarian activity in F1 cows under tropical conditions. J Anim Vet Adv. (9) 1: 79-84.

12. Fassi fihri, A., Lakhdissi, H., Derqaoui, L., Hajji, K.H, Naciri, M., Goumari, A (2005). Genetic and nongenetic effects on the number of ovarian follicles and oocyte yield and quality in the bovine local (Oulmes Zaer), exotic breeds and their crosses in Morocco. Afr. J.Biotech., 4 (1) : 9-13.

13. Gillund, P., Reksen, O., Grohn, Y.T., Karlberg, K (2001). Body condition related to ketosis and reproductive performance in Norwegian dairy cows. J. Dairy Sci. 84 1390-1396.

14. Grimard, B., Humblot, P., Ponter, A.A., Chastant, S., Constant, F., Mialot, J.P(2003). Efficacité des traitements de synchronisation des chaleurs chez les bovins. INRA. Prod. Anim., 16(3): 211-227.

15. Jilek, F., Pytloun, P., Kubešova, M., Štipkova, M., Bouška, J., Volek, J., Frelich, J., Rajmon, R (2008). Relationships among body condition score, milk yield and reproduction in Czech Fleckvieh cows. Czech J. Anim. Sci., 53, (9): 357-367

16. Jorritsma, R., Wensing, T., Kruip, T.A.M., Vos, P.L.A.M., Noordhuizen, J.P.T.M (2003). Metabolic changes in early lactation and impaired reproductive performance in dairy cows. Vet. Res. 34:11-26.

17. Khang'mate, A.B., Lahlou-kassi, A., Bakana, B.M., Kahungu M (2000). Performances de reproduction des bovins N'Dama dans le diocèse d'Idiofa au Congo. Revue Méd. Vét., 151, (6) : 511-516.

18. Kronfeld, D.S., Donoghue, S., Copp, R.L., Stearns, F.M., Engle, R.H (1982). nutritioal status of dairy cows indicated by analysis of blood. J Dairy Sci, 65 : 1925-1933.

19. Ling K., Jaakson H., Samarütel J., Leesmäe A., 2003. Metabolic status and body condition score of estonian holstein cows and their relation to some fertility parameters. Veterinarija Ir Zootechnika. T. 24 (46). 94-100.

20. Madani T., Mouffok C., (2008). production laitière et perfomances de reproduction des vaches Montbéliardes en région semi aride algérienne. Revue Elev. Méd. Vét. Pays trop, 61 (2): 97-107.

21. Mouffok C., Madani T., Yekhlef H., (2007). variation saisonnière des perfomances de reproduction chez la vache Montbéliarde dans le semi aride Algérien. Renc. Rech. Rum, 14, 5-6 dec.

22. Pruitt D., (2001). Managing young cows. Proceedings; the range beef cow symposium XVII Dec 11, 12 and 13, Casper, Wyoming.

23. Pryce J E., Coffey M P., Brotherstone S., (2000). The genetic relationship between calving interval, body condition score and linear type and management traits in registered Holsteins. J Dairy Sci 83:2664-2671.

24. Pryce J E., Coffey M P., Simm G., (2001). The relationship between body condition score and reproductive performance. J. Dairy Sci. 84:1508-1515.

25. Reksen O., Tverdal A., Ropstad E., (1999). A comparative study of reproductive performance in organic and conventional dairy husbandry. J Dairy Sci 82:2605-2610.

26. Roche J F. (2006). The effect of nutritional management of the dairy cow on reproductive efficiency. Anim Reprod Sci 96;282-296.

27. Royal M D., Pryce J E., Woolliams J A., Flint A P F., (2002) The genetic relationship between commencement of lutea activity and calving interval, body condition score, production, and linear type traits in Holstein-Friesian dairy cattle. J. Dairy Sci. 85:3071-3080.

28. Ruegg P L., Goodger W J., Holmberg C A., Weaver LD., Huffman E M., (1992). Relation among body condition score, milk production, and serum urea nitrogen and cholesterol concentrations in high producing holstein cows in early lactation. Am J Vet Res, 53:5-9.

29. Short R E., Bellows R A., Staigmiller R B., Berardinelli J G., Custer E E., (1990). Physiological mechanisms controlling anestrus and fertility in postpartum beef cattle. J. Anim. Sci, $68: 799-816$.

30. Shrestha H K, Nakao T, Suzuki T, Akita M, Higaki T. (2005). Relationships between body condition score, body weight, and some nutritional parameters in plasma and resumption of ovarian cyclicity postpartum during pre-service period in high-producing dairy cows in a subtropical region in Japan. Theriogenology 64 (2005) 855-866

31. Sraïri M T., Baqasse M., (2000). Devenir, performances de production et de reproduction de génisses laitières frisonnes pie noires importées au Maroc. Livestock Research for Rural Development (12) 3 .

32. Staples C R., Burke J M., Thatcher W W., (1998). Influence of supplemental fats on reproductive tissues and performance of lactating cows. J Dairy Sci 81:856-871.

33. Tillard E., Humblot P., Faye B., Lecomte P., Dohoo I., Bocquier F., (2007). precalving factors affecting conception risk in Holstein dairy cows in tropical conditions. Theriogenology. 68: 567-581.

34. Van Sanh M., Preston T R., Ly L V., (1997). Effects of restricted suckling versus artificial rearing on performance and fertility of crossbreed F1(Holstein Friesian x Local) cows and calves in Vietnam. Livestock Research for Rural Development (9) 4.

35. Veerkamp R F., Koenen E P C., De Jong G., (2001). Genetic correlations among body condition score, yield, and fertility in first-parity cows estimated by random regression models. J. Dairy Sci. 84:2327-2335.

36. Westwood C T., Lean I J., Garvin J K., (2002). Factors influencing fertility of Holstein dairy cows: a multivariate description. J. Dairy Sci. 85:3225-3237. 